\title{
Rekonstruksi Lembaga Pengadilan Menuju Indonesia Baru
}

\author{
Rusli Muhammad
}

The court (justice system) has noble duty and central position in a governanence, beside as a controller body, it is also as an institution which maintain law order in it's actualization in the real form. Meanwhile, this respectable position cannot be maintained properly and tends to deteriote as it shown by it's bad performances. There are three main problems appear, structural pioblem, legislation and human resources. Therefore the reconstruction of court system should be made by focusing on these problems.

embaga pengadilan mengemban tugas mulia dan memiliki posisi sentral dalam kehidupan bernegara, karena selain sebagai lembaga kontrol, lembaga ini pula mengantarkan aturan-aturan hukum dapat diaktualisasikan dalam wujud nyata. . Namun posisi dan kedudukan yang mulia itu tidak mampu dipertahankan dan rasanya kian hari kian terkikis oleh perilaku-perilaku buruk yang ditampilkannya. Berbagai agenda persoalan muncul berhubungan langsung dengan lembaga pengadilan misalnya, masalah struktural, perundangundangan dan personal pengadilan (hakim). Oleh karena itu, , upaya rekonstruksi lembaga pengadilan dilakukan dengan memfokuskan perhatian pada persoalanpersoalan tersebut melalui upaya restrukturisasi pengadilan, reformasi terhadap perundang-undangan dan revitalisasi pengadilan.

Lembaga pengadilan sebagai salah satu dari pranata hukum selalu menjadi obyek kajian dan selalu menjadi pembicaraan hangat. Pembicaraan ini tidak saja secara perseorangan melalui tulisantulisan di berbagai media massa tapi juga melalui pertemuan-pertemuan ilmiah yang diselenggarakan oleh berbagai kalangan. Hampir setiap hari dapat ditemukan berita, laporan ataupun ulasan yang berhubungan dengan pengadilan.

Perhatian terhadap lembaga pengadilan tidak lepas dari adanya peranan terhormat dan strategis yang dimilikinya. Lembaga pengadilan merupakan keharusan bagi setiap negara yang mengklaim dirinya sebagai negara hukum karena pada negara yang memiliki lembaga pengadilan seperti itulah dapat melaksanakan hukum yang bersifat abstrak ke dalam peristiwa-peristiwa yang konkret. Peranan dan kedudukan lembaga pengadilan yang terhormat itu, rasanya kian hari kian terkikis oleh perilakuperilaku yang ditampilkannya dan kini semakin banyak orang yang tidak menaruh hormat bahkan dengan penuh keprihatinan memberikan kritik-kritik tajam atasnya.

Keadilan yang merupakan salah satu dari masalah-masalah sentral yang menjadi 
tugas pokok dan utama pengadilan, ternyata telah tergeser oleh masalah-masalah lainnya yang menjadi kepentingan kekuasaan negara atau kekuatan-kekuatan fungsional lain. Lembaga pengadilan sekarang ini cenderung lebih mengutamakan kepentingan ekonomi, kepentingan politik dibanding dengan kepentingan keadilan.

Bergesernya perhatian pengadilan dari masalah keadilan menjadikan lembaga ini semakin tergeser dan akan menjadi lembaga yang semakin termarginalkan. Dengan demikian, lembaga pengadilan tidak dapat lagi disejajarkan dengan lembagalembaga kekuasaan negara lainnya yang mandiri dan menentukan, pengadilan telah kehilangan fungsinya. Jika fungsi itu masih ada, fungsi itu tidak lebih sekedar pengabsahan dan penyambung keinginan dari kepentingan-kepentingan tertentu sekalipun menyimpang dari keadilan yang seharusnya diutamakan.

Sinyalemen yang menyatakan bahwa pengadilan bergeser menjadi lembaga pinggiran akan sangat terasa dan akan terjadi bila masalah keadilan dihadapkan dengan masalah-masalah sentral lainnya, seperti ekonomi, keuangan, politik. Dalam hal ini Satjipto Rahardjo mengatakan : "Dalam suasana pembangunan yang sangat menekankan aspek ekonomi sekarang ini, manajemen keadilan terasa terdorong ke belakang. Berbagai institusi ekonomi, produksi dan keuangan berada di pusat, sedangkan institusi keadilan berada dipinggiran atau periferi. ${ }^{1}$

Tekanan-tekanan dari institusi-institusi kekuasaan negara dan kekuatan-kekuatan lain dengan membawakan misi ekonomi, dan terkadang misi politik dihadapkan dengan misi keadilan membuat pengadilan harus menentukan pilihan, apakah tetap eksis sebagai lembaga sentral dan tetap pada peranannya sebagai pengemban keadilan sederajat dengan lembaga lainnya ataukah harus menjadi lembaga pinggiran yang selalu tersingkirkan. Kondisi obyektif menunjukkan bahwa ternyata pengadilan lebih cenderung menempatkan dirinya sebagai lembaga pinggiran.

Sekarang ini tekanan-tekanan kepada lembaga pengadilan bukan saja datang dari kekuasaan negara dan kekuatan-kekuatan berpengaruh dalam masyarakat, tapi tekanan itu muncul juga dari berbagai kalangan masyarakat terutama para pencari keadilan dan para cendikiawan sekalipun masing-masing tekanan ini tujuannya berbeda. Jika tekanan dari kekuasaan negara atau birokrat-birokrat eksekutif dan kekuatan-kekuatan fungsional lainnya bertujuan untuk menjadikan pengadilan sebagai lembaga pinggiran yang selalu memuluskan dan melindungi kepentingankepentingannya, maka tidak demikian halnya dengan tekanan dari masayarakat pencari keadilan. Tekanan dari masyartakat itu ditujukan kepada perilaku-perilaku negatif pengadilan dengan tujuan agar pengadilan kembali kepada posisinya sebagai lembaga penegak keadilan.

Tekanan ataupun kritikan kepada pengadilan dapat saja dimaklumi karena masyarakat sangat menginginkan agar pengadilan itu dapat memberikan keadilan kepada masyarakat, namun keinginginan ini justru kadang bertolak belakang dengan apa yang diberikan oleh pengadilan. Putusanputusan yang dihasilkan, oleh masyarakat dianggap kurang atau bahkan tidak adil. Sementara itu perilaku-perilaku personalnya terkadang tidak mencerminkan sebagai

1 Satjipto Rahardjo, Pemberdayaan Mahkamah Agung ", dalam Gema Kliping Servis, Mei II 1997, hal 1. 
personil'penegak hukum yang memiliki jiwa profesionalisme, etika dan kepribadian yang tinggi, misalnya: perkelahian, pertengkaran sesama hakim, adanya ancaman fisik, tawar menawar perkara, kolusi, penembakan di ruang sidang dan lain sebagainya.

Kondisi lembaga pengadilan yang demikian memerlukan upaya perbaikan kembali kepada seluruh komponen yang berhubungan langsung dengan lembaga pengadilan. Persoalannya adalah apa yang menjadi agenda dan langkah-langkah apa yang dilakukan di dalam membangun kembali lembaga pengadilan menuju Indonesia baru? Persoalan inilah yang akan dibahas dalam tulisan ini.

\section{Agenda Rekonstruksi Lembaga Pengadilan}

Untuk mendapatkan hasil yang representatif, maka rekonstruksi lembaga pengadilan hendaknya di arahkan kepada persoalan-persoalan yang berhubungan langsung dengan lembaga pengadilan itu. Terdapat tiga komponen pokok yang perlu mendapat perhatian dalam melakukan rekonstruksi lembaga pengadilan, yakni faktor struktur, peraturan hukum dan personil pengadilan (hakim). Pilihan terhadap ketiga faktor ini karena dalam kenyataan sumber masalah yang terjadi dalam lingkungan lembaga pengadilan lebih banyak muncul dari ketiga komponen te.rsebut .

Agenda rekonstruksi terhadap faktor struktur adalah berkaitan dengan dominannya kekuasaan eksekutif terhadap lembaga (badan) peradilan yang nota bene sebagai lembaga pemegang dan pelaksanaan kekuasaan kehakiman. Keterlibatan kekuasaan eksekutif yang dirasakan sangat mengganggu adalah pada urusan organisasi, administrasi dan finansial. Persoalan ini sebenarnya telah dilakukan perubahan melalui amandemen UUD 1945 dan dengan dikeluarkannya undang-undang yakni Undang-Undang Nomor 35 tahun 1999 tentang Perubahan terhadap Undang-Undang Pokok Kekuasaan Kehakiman Nomor 14 tahun 1970, dan kemudian dirubah lagi dengan UU Nomor 4 Tahun 2004. Meskipun secara yuridis telah dilakukan berubahan ,namun realisasinya hingga saat ini belum juga dilaksanakan.

Jaminan kekebalan dan kesejahteraan komponen peradilan adalah juga persoalan struktural yang perlu mendapat perhatian. Selama ini kekebalan hakim adalah sangat rapuh karena belum adanya jaminan undangundang yang memberi perlindungan terhadap persoalan tersebut. Tak kalah pentingnya pula adalah masalah kesejahteraan hakim. Masalah ini sangat memprihatinkan, gaji dan tunjangan sosial masih jauh lebih rendah bila dibandingkan dengan gaji atau tunjangan wakil-wakil rakyat di DPR, belum lagi bila dibandingkan dengan manajer atau direktur suatu perusahaan baik milik negara maupun milik suwasta.

Persoalan kewenangan melakukan Hak Uji Materiil (Judicial Review) terhadap semua peraturan perundang-undangan adalah juga persoalan struktural yang perlu pula mendapat perhatian. Selama ini lembaga pengadilan (Mahkamah Agung) hanya berhak menguji peraturan perundangundangan di bawah undang-undang. Jika menyangkut Undang-undang Mahkamah Agung tidak memiliki kewenangan untuk itu, sementara persoalan yang muncul di sekitar undang-undang cukup banyak.

Adapun agenda rekonstruksi di bidang peraturan hukum tidak terbatas pada peraturan organik melainkan harus menjangkau pada konstitusi (UUD) dan harus menjadi pilihan dalam melakukan 
rekonstruksi itu. Pemilihan UUD sebagai agenda rekonstruksi karena mengingat status dan posisi UUD sangat vital dalam sistem hukum Indonesia. Namun tidak menutup kemungkinan terjadinya berbagai permasalahan yang tidak menyenangkan dalam dunia hukum (peradilan) serta terjadinya ketimpangan-ketimpangan dalam ketatanegaraan kita selama ini, terutama hilangnya kebebasan kekuasaan kehakiman dalam upaya penegakan hukum tidak semata-mata bersumber dari pelaku-pelaku dari para penyelenggara negara atau para penegak hukum tetapi kemungkinan besar justru berasal dari ketidak beresan UUD 1945 itu sendiri

Setelah UUD sebagai agenda pertama, agenda berikutnya di bidang peraturan hukum adalah terhadap Undang-Undang Nomor 4 Tahun 2004 yakni Undang-Undang Tentang Kekuasaan Kehakiman. Undangundang ini di buat dalam rangka penyesuaian terhadap amandemen UUD khususnya mengenai kekuasaan kehakiman, sekaligus menyatakan Undang-Undang Nomor 14 Tahun 1970 tentang Ketentuan-ketentuan Pokok Kekuasaan Kehakiman sebagaimana telah diubah dengan Undang-Undang Nomor 35 Tahun 1999 tentang Perubahan Atas Kekuasaan Kehakiman dinyatakan tidak berlaku.

Selain kedua hal tersebut di atas, peraturan hukum lainnya yang perlu mendapat reformasi adalah Undang-Undang Nomor 2 Tahun 1986. Undang-undang ini sudah tidak relevan lagi karena ia merupakan pelaksanaan ketentuan-ketentuan dan asasasas yang tercantum di dalam Undangundang Nomor 14 Tahun 1970, sementara undang-undang ini telah diubah dan dicabut dengan Undang-Undang Nomor 4 Tahun 2004. Oleh karena itu ke depan perlu segera menyusun Undang-Undang Tentang
Peradilan Umum menggantikan UndangUndang Nomor 2 Tahun 1986 tersebut.

Sementara itu, agenda rekonstruksi komponen lembaga pengadilan menyangkut faktor personil pengadilan (hakim) adalah berkaitan langsung dengan keberadaan hakim itu sendiri. Hakim sebagai faktor sentral lembaga pengadilan menyimpan berbagai persoalan yang menuntut segera dilakukan prebaikan-perbaikan. Kemampuan profesional para hakim nampaknya tidak perlu diragukan mengingat pengalaman mereka sangat mendukung hal itu. Namun kemampuan teoritik nampaknya masih jauh tertinggal. Kelemahan pada dataran teoritik akan dapat berpengaruh kepada hasil kerjanya. Putusan-putusan yang dihasilkan tanpa didukung oleh kemampuan teoritik menyebabkan putusan itu menjadi hampa dan kering karena hanya berisikan sekumpulan dogma yuridis semata.

Hal lain yang juga perlu mendapat perhatian adalah pada peran dan tanggung jawab yang harus dipikul oleh hakim sebagai pendukung utama lembaga pengadilan. Peranan dan tanggung jawab hakim sebenarnya telah diisyaratkan di dalam konstitusi, namun peranan dan kedudukan lembaga pengadilan yang terhormat itu, rasanya semakin rusak oleh perilakuperilaku yang ditampilkannya, kebanyakan para hakim disinyalir telah mengabaikan peran dan tanggung jawabnya, mereka lebih cenderung memihak kepada. penguasa dan pengusaha yang berduit ketimbang memihak kepada kebenaran dan keadilan.

Agenda rekonstruksi yang penting lainnya berhubungan dengan faktor hakim adalah menyangkut moralitas para hakim. Persoalan ini menjadi agenda mengingat demikian pentingnya di dalam kehidupan manusia, karena dengan moral manusia 
akan mampu mengantarkan pada perilaku kehidupan yang mulia dan terhormat. Namun dalam prakteknya apa yang diperlihatkan oleh sebahagian para hakim justru memperlihatkan berbagai tindakan yang tidak bermoral. Kondisi demikian menuntut persoalan moral menjadi agenda perhatian di dalam membangun kembali lembaga pengadilan.

\section{Upaya Rekonstruksi Lembaga Pengadilan}

Untuk menentukan upaya di dalam membangun kembali lembaga pengadilan tidak dapat dipisahkan dengan berbagai agenda persoalan sebagaimana yang telah disebutkan di atas. Demikian pula tidak dapat dipisahkan dengan beberapa teori yang dapat menjadi dasar pijakan di dalam menentukan dan memilih upaya rekonstruksi lembaga pengadilan.

Pada kajian sosiologis memperlihatkan adanya kekuatan-kekuatan yang berpengaruh yang saling berhubungan secara timbal balik di dalam melakukan sebuah rekayasa masyarakat. Oleh karena itu menarik apa yang dikatakan oleh Seidmen yang menggambarkan adanya tiga kekuatan pengaruh yang secara timbal balik saling berhubungan dalam kaitannya dengan Social engineering. Ketiga kekuatan tersebut adalah: ${ }^{2}$ Pertama, pembentuk undang-undang.. Kedua, pemegang peranan (warga negara) dan ketiga adalah pelaksana. Ketiga kekuatan inilah yang secara bersama-sama dan seimbang perlu mendapat perhatian, artinya tidak akan mungkin sebuah undang-undang yang dihasilkan oleh pembentuk undang-undang bejalan dengan efektif tanpa memperhatikan pemegang peran dan pelaksananya, demikian pula sebaliknya. Oleh karena.itu pemahaman yang menyeluruh kepada masing-masing kekuatan itu harus mendapat perhatian sewajarnya, termasuk juga di dalam menentukan upaya dalam pembangunan kembali lembaga pengadilan.

Selain ajaran tersebut di atas, ajaran Friedman tentang sistem hukum (legal system) perlu pula mendapat perhatian. Menurut Lawrence M. Friedman, sistem hukum terdiri dari 3 (tiga) komponen, yakni Structure, Substance dan legal Culture. ${ }^{3}$ Komponen strukturyang dimaksud adalah bentuk yang permanen, badan institusi yang bekerja mengikuti proses-proses dalam batasanbatasannya. Substansi adalah norma-norma atau aturan-aturan aktual yang digunakan oleh institusi yang menentukan cara-cara menggambarkan suatu perilaku dan menentukan kemungkinan ke arah mana bertindak. Sementara budaya hukum adalah elemen sikap dan nilai sosial yang diwujudkan di dalam tingkah laku konkret masyarakat.

Berdasarkan berbagai agenda dan ajaran tersebut di atas, maka uapaya rekonstruksi lembaga pengadilan dapat di lakukan melalui tiga macam upaya yaitu:

1. Upaya restrukturisasi pengadilan.

2. Upaya reformasi peraturan hukum.

3. Upaya revitalisasi lembaga pengadilan.

2 Robert B. Seidman, dảlam, Satjipto Rahardjo, Hukum Dan Perubahan Sosial, Bandung : Penerbit Alumni , 1983, hlm 161.

${ }^{3}$ Lawrence M. Friedman. "The Legal System, A Social Science Perspective" (Russell Sage Foundtion. New York 1975). Pp 14-15. $\mathrm{Hal}$ yang sama dapat pula dilihat di dalam bukunya yang lain yakni "Law And Society An Introduction" (Prentice-Hall, inc,. Rnglewood Cliffs, N.J. 07632, United States of America, 1977) Pp 6-9. 


\section{Upaya Restrukturisasi Pengadilan}

Upaya ini dimaksudkan untuk membenahi kembali kondisi pengadilan khususnya menyangkut masalah-masalah struktural pengadilan. Dengan memperhatikan agenda persoalan di sekitar struktur lembaga pengadilan, maka upaya. restrukturisasi yang dapat dilakukan adalah:

Pertama, pemisahan kekuasaan yudikatif dari eksekutif. Usaha pemisahan kekuasaan yudikatif dengan kekuasaan eksekutif sebenarnya telah dimulai dengan dikeluarkannya Ketetapan MPR No. X/MPR/ 1998 tanggal 13 November 1998 tentang Pokok-Pokok Reformasi Pembangunan Dalam Rangka Penyelamatan dan Normalisasi kehidupan Nasional sebagai Haluan Negara yang menghendaki adanya pembagian secara tegas wewenang kekuasaan antara eksekutif, legislatif, dan yudikatif. Kemudian usaha ini dilanjutkan melalui amandemen UUD 1945 hingga dikeluarkannya undang-undang baru tentang Kekuasaan Kehakiman yakni UU Nomor 35 Tahun 1999 kemudian dicabut dengan UU No. 4 Tahun 2004. Namun apa yang diinginkan oleh undang-undang ini realisasinya hingga saat ini belum juga dilaksanakan

Kedua, perbaikan tingkat kesejahteraan komponen pengadilan. Tidak kalah pentingnya untuk mendapat perhatian adalah perbaikan kesejahteraan para komponen pengadilan terutama hakim. Pentingnya memperbaiki kesejahteraan para hakim, karena faktor ini sering menjadi alasan terjadinya penyalah gunaan wewenang atau tindakan tidak bermoral yang dipraktekkan oleh para hakim. Rendahnya gaji, tidak adanya jaminan sosial, kurangnya tunjangan jabatan terlalu sering dijadikan alasan untuk mengukur hasil kerja pengadilan.
Terkait dengan itu, mengingat mayoritas rakyat Indonesia beragama Islam, maka peran agama perlu dilihat. Dalam pandangan Islam faktor perbaikan taraf hidup (kesejahteraan) adalah suatu keharusan yang tidak boleh dilalaikan. Islam mengharuskan agar setiap individu senantiasa berbuat untuk mendapatkan kehidupan yang lebih baik, hari ini harus lebih baik dari hari kemarin dan hari esok harus lebih baik dari hari ini. Islam tidak menghendaki umatnya berada di dalam kehidupan yang miskin dan sengsara, karena kehidupan yang demikian cenderung kepada kekafiran. Oleh karena itu, kebahagiaan, kesejahteraan harus diperjuangkan dan diraih, bukankah Allah telah berfirman :

"Dan carilah pada apa yang telah dianugerahkan Allah kepadamu (kebahagiaan) negeri akhirat, dan janganlah kamu melupakan bahagiaanmu dari (kenikmatan) dunia dan berbuat baiklah (kepada orang lain) sebagaimana Allah telah berbuat baik kepadamu, dan janganlah kamu berbuat kerusakan di (muka) bumi. Sesungguhnya Allah tidakmenyukaiorang-orang yang berbuat kerusakan ( $A$ ) Qashash. 28:77).

Rendahnya kesejahteraan adalah gambaran kemiskinan, dan iniakan berakibat fatal bagi suatu kehidupan, baik kehidupan individu, kelompok/golongan ataupun kehidupan bernegara, karena kehidupan akan menjadi goyah, rapuh dan mudah runtuh ketika badai menghantamnya. Adalah benar ajaran agama (Islam) sebagaimana telah disabdakan oleh Nabi Muhammad, bahwa kemiskinan lebih dekat ke pada kekufuran. Sejalan pula dengan itu Allah. berfirman:

"Setan menjanjikan (menakut-nakuti) kamu dengan kemiskinan dan 
menyuruh kamu berbuat jahat."

Menyadari akan akibat yang ditimbulkan, maka adalah wajar manakala timbulnya dorongan kuat untuk lebih memperhatikan tingkat kesejahteraan dan lebih berupaya untuk mendapatkan kesejahteraan. Kita dapat mempredikisi bahwa ketika orang akan bekerja dengan terlebih dahulu mengetahui sesuatu yang akan diperolehnya, maka akan memberi dorongan motivasi dalam melakukan pekerjaannya itu. Jika gambaran yang akan diterima itu tidak akan mensejahterakan dirinya, keluarganya, maka motivasi dan semangatnya akan rendah, sebaliknya jika gambaran yang akan diterima akan dapat meningkatkan kesejahteraan, maka motivasi dan semangat kerjanya tentu akan lebih baik.

Ketiga, pembentukan komisi yustisial (justicial comission). Untuk meningkatkan checks and balances terhadap lembaga pengadilan khususnya mencermati putusanputusan hakim yang dirasakan tidak adil dan mendapat respon berbagai kalangan, perlu dibentuk Komisi Yustisial (Justicial Comission) atau sebuah Dewan Kehormatan yang berwenang:

1) Mengawasi perilaku hakim, termasuk melakukan pengawasan terhadap putusan-putusan pengadilan.

2) Memberikan rekomendasi dalam rekruitmen, promosi dan mutasi hakim;

3) Menyusun code of condact bagi para hakim.

Dalam rangka pengawasan terhadap perilaku dan terhadap putusan pengadilan, maka Komisi Yustisial (Dewan Kehormatan) dapat menampung pengaduan para pencari keadilan terhadap suatu putusan yang dianggap bertentangan dengan kepastian hukum dan rasa keadilan. Putusan yang dikeluarkan tersebut tidak akan diubah sekalipun ada pengaduan masyarakat.
Komisi Yustisial akan melakukan dengar pendapat dengan pihak pelapor dan majelis hakim yang memutus perkara tersebut. Rekomendasi yang disampaikan kepada Mahkamah Agung nantinya maksimal berupa usulan pemecatan terhadap seorang hakim yang dinilai telah berbuat salah.

Pengangkatan dan Pemberhentian anggota Komisi Yustisial dilakukan oleh DPR atas usul Pemerintah. Peraturan lebih rinci tentang Komisi ini harus dimuat di dalam UU Mahkamah Agung RI. Sementara Dahlan Thaib di dalam makalahnya mengusulkan bahwa, Komisi yustisial adalah komisi independen yang beranggotakan 9 (sembilan) orang yang berpengalaman dalam profesi hukum, memiliki integritas dan kepribadian yang tidak tercela, sehat fisik dan mental, berusia sekurang-kurangnya 45 tahun. ${ }^{4}$.

Keempat, penyempurnaan kewenagan dan susunan organisasi. Upaya restrukturisasi pengadilan guna mengembalikan pengadilan tersebut sebagai pengemban dan pelaksana kekuasaan kehakiman yang bebas dan mandiri, maka menjadi keharusan untuk mengembalikan kewenangan Mahkamah Agung dalam fungsinya menguji hukum secara utuh .Oleh karena itu Hak Uji Materiil (Judicial Review) yang selama ini terbatas pada peraturan-peraturan di bawah undang-undang tidak dapat dipertahankan lagi, ke depan ketentuan ini perlu diubah sehingga' Hak Uji Materiil terhadap semua perundang-undangan

${ }^{4}$ Dahlan Thaib, "Struktur dan Organisasi Mahkamah Agung" (makalah dalam Workshop "Perbaikan kedudukan, kekuasaan, Organisasi, Adiminstrasi dan Managemen Mahkamah Agung dan lain-lain badan Peradilan di bawahnya, diselenggrkan oleh IKÄHI Yogyakarta tanggal 27-28 Agustus 2001) hal. 8-9. 
adalah dikembalikan menjadi wewenang eksklusif badan peradilan. Dengan demikian, ketentuan di dalam UUD hasil amandemen yang membatasi hak uji materiil Mahkamah Agung itu perlu ditinjau kembali melalui amandemen berikutnya.

Memperhatikan fungsi Mahkamah Agung maka, perlu memberdayakan Mahkamah Agung dengan cara menyempurnakan struktur organisasinya dan meningkatkan kualitas SDMnya. Oleh karena itu, ke depan organisasi Mahkamah Agung harus dilengkapi dengan berbagai bidang sesuai dengan fungsi-fungsi yang dimilikinya. Tidak saja Mahkamah Agung yang dilengkapi susunan organisasinya, namun hal yang sama pula dilakukan kepada Pengadilan Tinggi dan Pengadilan Negeri dengan menyesuaikan dengan Mahkamah Agung sepanjang hal tersebut dibutuhkan dan ada relevansinya. Untuk itu di tingkat Pengadilan Tinggi perlu pula dibentuk unit pengawasan dalam struktur organisasinya yang dipimpin seorang hakim Tinggi yang bertanggung jawab kepada Ketua Pengadilan Tinggi., demikian pula di tingkat Pengadilan Negeri

\section{Upaya Reformasi Peraturan Hukum}

Reformasi terhadap peraturan hukum tidak terbatas pada peraturan organik melainkan harus menjangkau pada konstitusi (UUD) dan harus menjadi pilihan pertama dalam melakukan reformasi itu. Pemilihan UUD sebagai sasaran pertama reformasi karena mengingat status dan posisi UUD sangat vital dalam sistem hukum Indonesia. Namun tidak menutup kemungkinan terjadinya berbagai permasalahan yang tidak menyenangkan dalam dunia hukum (peradilan) serta terjadinya ketimpangan-ketimpangan dalam ketatanegaraan kita selama ini, terutama hilangnya kebebasan kekuasaan kehakiman dalam upaya penegakan hukum tidak semata-mata bersumber dari pelaku-pelaku dari para penyelenggara negara atau para penegak hukum tetapi kemungkinan besar justru berasal dari ketidakberesan UUD 1945 itu sendiri

Kekuasaan Kehakiman yang diharapkan sebagai pengimbang terhadap kekuasaan lainnya, sungguh disayangkan ternyata rumusan-rumusan pasal UUD 1945 tidak banyak dimuat, hanya menyebutkan dua pasal untuk kekuasaan kehakiman (Pasal 24 dan 25). Lebih ironisnya lagi tidak ada pasal yang menyebutkan tentang jaminan kemerdekaan kekuasaan kehakiman. Penyebutan kalimat Kekuasaan Kehakiman yang merdeka baru ditemukan pada penjelasan pasal. Kiranya dapat dipahami bahwa materi dari UUD 1945 yang penuh dengan kelemahan-kelemahan tersebut hanya menguntungkan bagi penguasa eksekutif semata, sementara kekuasaan-kekuasaan lainnya seperti yudikatif dan legislatif demikian pula hakhak rakyat kurang mendapat perhatian.

Sesungguhnya telah dilakukan Amandemen terhadap UUD 1945 sehinga telah terjadi beberapa perubahan-perubahan yang cukup prinsipil, namun beberapa perubahan itu masih menyisakan berbagai permasalahan. khususnya berkaitan dengan konsep Kekuasaan Kehakiman, Mahkamah Konstitusi, hak uji materiil bagi Mahkamah Agung dan kemandirian pengadilan itu sendiri sehinga masih perlu reformasi melalui amandemen berikutnya..

Setelah UUD sebagai agenda pertama reformasi, pilihan reformasi di bidang peraturan hukum lainnya adalah reformasi terhadap Undang-Undang Nomor 4 Tahun 2004 yakni Undang-Undang Tentang Kekuasaan Kehakiman. Undang-undang ini di buat dalam rangka penyesuaian terhadap 
amandemen UUD khususnya mengenai kekuasaan kehakiman, sekaligus menyatakan Undang-Undang Nomor 14 Tahun 1970 tentang Ketentuan-ketentuan Pokok Kekuasaan Kehakiman sebagaimana telah diubah dengan Undang-Undang Nomor 35 Tahun 1999 tentang Perubahan Atas Kekuasaan Kehakiman dinyatakan tidak berlaku.

Sekalipun undang-undang ini telah banyak melakukan perubahan terhadap materi undang-undang sebelumnya, namun tidak berarti undang-undang ini telah menutup dilakukannya reformasi. Undangundang Nomor 4 Tahun 2004 ternyata masih juga meninggalkan persoalan sehingga masih perlu dilakukan reformsi lebih lanjut. Persoalan-persoalan yang tersisa dari undang-undang ini adalah lagi-lagi kekuasaan kehakiman mengalami pembatasan, yakni terbatas pada kekuasaan mengadili yang dilakukan oleh Mahkamah Agung dan badan peradilan yang berada di bawahnya dalam berbagai lingkungan peradilan. Ketentuan ini tidak berbeda dengan rumusan UUD hasil amandemen yang membatasi kekuasaan kehakiman terbatas pada kekuasaan mengadili di luar kekuasaan penyidikan dan penuntutan.

Undang-Undang Nomor 4 Tahun 2004 ini kembali mempertegas ketentuan UndangUndang Dasar tentang kedudukan Mahkamah Konstitusi dan kewenangan melakukan Hak Uji Materiil undang-undang terhadap Undang-Undang Dasar. Ini berarti persoalannya adalah sama halnya dengan apa yang telah disinggung di atas yang berarti menghendaki pula undang-undang ini di reformasi..

Jika Undang-Undang Nomor 4 Tahun 2004 memuat hal-hal baru (namun menimbulkan perdebatan), ternyata terdapat persoalan prinsip terabaikan oleh undang- undang ini, yakni tidak adanya ketentuan tentang jaminan profesi berupa immunitas atau perlindungan bagi para hakim ketika menjalankan profesinya. Tidak adanya jaminan seperti itu akan menimbulkan kehawatiran bahkan ketakutan bagi para hakim karena mungkin saja sewaktu-waktu dalam menjalankan atau setelah selesai menjalankan profesinya mereka dapat dituntut atau dicopot dari jabatannya.

\section{Upaya Revitalisasi Lembaga Pengadilan}

Upaya revitalisasi pengadilan dimaksudkan sebagai suatu usaha untuk mengembalikan pengadilan menjadi lembaga yang bermakna, lembaga yang kembali kepada fungsi yang sesungguhnya dan lembaga yang penting bagi kehidupan masyarakat. Revitalisasi sendiri mengandung pengertian mengembalikan agar lembaga peradilan hidup dan berfungsi kembali. ${ }^{5}$ Berdasarkan atas agenda persoalan berkaitan dengan personil pengadilan, maka upaya revitalisasi dalam rangka rekonstruksi lembaga pengadilan dapat dilakukan dengan cara:

Pertama, peningkatan kualitas teoritik. Usaha ini memfokuskan perhatian kepada kualitas teoritik personil yang harus dimiliki oleh jajaran penegak hukum. Untuk meningkatkan kualitas dari penegak hukum itu perlu diupayakan agar jenjang pendidikan yang selama ini hanya terbatas pada tingkat sarjana (S-1) lebih ditingkatkan lagi dengan mengikuti pendidikan pada jenjang yang lebih tinggi S-2 atau S-3.

${ }^{5}$ Sudikno Mertokusumo, "Revitalisasi dan Fungsionalisasi Lembaga Peradilan ", Makalah pada Diskusi "Usulan Rancangan GBHN '98 Fakultas Hukum UII Yogyakarta, 15 Juli 1987, hal 2. 
Kemampuan berpikir teoritis hanya dapat diperoleh melalui jenjang pendidikan yang lebih tinggi. Oleh karena itu pendidikan ke jenjang lebih tinggi terutama pada hakim mutlak diperlukan. Dengan berkemampuan teoritik, lembaga pengadilan melalui SDMnya akan selalu berpikir rasional dan bertindak dengan mempertimbangkan berbagai aspek, paling tidak aspek yuridis, sosiologis dan aspek filosofis. Pikiran-pikiran dan pertimbangan-pertimbangan yang demikian akan mengurangi pengadilan dari pikiranpikiran yang praktis, yakni suatu pikiran yang dapat diibaratkan tukang-tukang yang menerima pesanan dan bekerja sesuai dengan isi pesanan tanpa ada kebebasan untuk berkarya dan berkreasi kepada hasilhasil yang lebih sempurna (keadilan).

Kedua, peningkatan kesadaran peran dan tanggung Jawab. Dalam upaya revitalisasi pengadilan, maka posisi pengadilan yang telah terpinggirkan hendaknya dikembalikan ke posisi sentral. Untuk mengembalikan posisi tersebut, hanya dapat dicapai jika para hakim sebagai komponen pokok pengadilan lebih meningkatkan kesadaran akan peran dan tanggung jawabnya. Para hakim harus sungguh menyadari tentang perananperanan baik yang bersifat yuridis formal maupun yang bersifat yuridis materiil' . $^{\text {. }}$

Mengenai tugas dan tanggung jawab pengadilan (hakim) menarik bila mengutip pendapat Soejono Koesoemo Sisworo. Menurutnya, pada hakikatnya tugas dan fungsi hakim adalah melakukan penemuan hukum dengan hasil keputusan hati nurani/ gewetensbeslissing terhadap perkara yang diajukan kepadanya untuk diperiksa dan diadili. Pada bagian lain disebutkan pula bahwa tugas dan fungsi hakim pada hakikatnya juga menciptakan harmoni antara das sein dan das sollen, merujukkan these dan anti these sehingga berpadu serasi menjadi sinthese ${ }^{7}$.

Bila melihat fungsi dan karya-karya pengadilan (hakim) yang demikian itu, ini berarti bahwa pengadilan tidak sekedar menerapkan peraturan hukum secara mekanis-sylogisme belaka, tetapi lebih dari itu yaitu harus mampu sebagai pencipta, pembentukan atau penemuan hukum yang di samping melibatkan cipta (logos), karsa (etos) dan rasa (pathos), yang terpenting juga mempertaruhkan hati nurani dan intuisi yaitu rasa halus yang khusu'tinarbuka memohon hidayah-inayah Tuhan Seru Sekalian Alam. ${ }^{8}$ Sebagai konsekuensi dari peningkatan peran maka hakim dituntut pula lebih meningkatkan kesadarannya akan tanggung jawab, yakni tanggung jawab kepada hukum, masyarakat dan terutama kepada Tuhan.

6 Peran yang berisfat yuridis formal dimaksud adalah peran yang dijalankan oleh Lembaga peradilan berdasarkan ketentuan undang-undang, yaitu melaksanakan peraturan perundang-undangan melalui kegiatan berupa menerima, memeriksa, mengadili dan menjatuhkan putusan.. Sedangkan peran yang bersifat yuridis materiil adalah peran yang dijalankan oleh lembaga peradilan berdasarkan hati nurani, diskresi dan kondisi-kondisi sosial politik tertentu melalui berbagai bentuk kegiatan ke arah tegaknya hukum, keadilan, dan perlindungan terhadap harkat dan martabat manusia, ketertiban, ketentraman, keamanan dan kesejahteraan masyarakat sebagaimana yang telah diamanatkan oleh konstitusi 1945. Istilah yuridis materiil ini, diilhami oleh istilah "Penegakan Hukum Secara Material" yang dikemukakan oleh Barda Nawawi Arief dalam bukunya "Beberapa Aspek Kebijakan Penegakan dan Pengembangan Hukum Pidana (Bandung : Penerbit Aditya Bakri, 1998) hal 7 .

7 Soejono Koesoemo S, "Beberapa Pemikiran tentang Filsafat Hukum" (Semarang UNDIP, tanpa tahun) hal. 58.

8 Ibid, halaman 51. 
Nampaknya yang perlu diperhatikan, direnungkan dan lebih ditingkatkan adalah tanggung jawab kepada Tuhan, karena ini merupakan amanat bagi setiap manusia sebagai ciptaan Allah. Demikian itu adalah konsekwensi sebagai hamba dan abdi Tuhan yang telah menerima perjanjian dengan Allah ${ }^{9}$. Dapat diyakini bahwa, dengan tingginya kesadaran akan tanggung jawab ke pada Tuhan akan dapat mengendalikan setiap nafsu setaniah yang ada di dalam diri setiap mansuia.

Ketiga, perbaikan moral komponen pengadilan (hakim). Timbulnya kesadaran akan adanya tanggung jawab sangat tergantung kepada baik buruknya moral (akhlak) yang dimilikinya. Ketika moralnya baik, maka kesadaran terhadap tanggung jawab akan baik pula, sebaliknya jika moral buruk akan berakibat pula pada rendahnya kesadaran tanggung jawab. Oleh karena itu untuk menyadarkan tumbuhnya kesadaran akan tanggung jawab, maka persoalan moral perlu mendapat perhatian.

Langkah perbaikan moralitas komponen pengadilan sudah saatnya harus dilakukan dan digalakkan mengingat moral para penegak hukum pada umumnya dapat dikatakan berada pada titik terendah, dan inilah salah satu faktor yang mempengaruhi rendahnya kinerja lembaga pengadilan sehingga sulit menjalankan keseluruhan peran-peran yang dimilik.inya. Memang tidak dapat disangkal bahw'a kecenderungan melakukan sesuatu perbuatan apakah itu menjurus kepada kebaikan atau kepada keburukan tergantung kepada landasan moral atau akhlaknya masing-masing, jika akhlaknya termasuk akhlak mahmudah, ${ }^{10}$ maka perbuatan yang dilakukan menjurus kepada kebaikan, sebaliknya jika akhlaknya. termasuk akhlak madzmumah" , maka perbuatannya akan cenderung menghasilkan keburukan, kenistaan dan kerusakan.

Persoalannya adalah langkah apa yang dapat dilakukan agar moral mahmudah ini menjadi bagian dari kehidupan setiap komponen hakim pengadilan? Langkahnya tidak sukar untuk dapat menghasilkan akhlak mahmudah itu, karena cukup dengan memperbanyak kesempatan untuk dapat mengetahui ajaran-ajaran agama dan mengaktualisasikannya dalam kehidupan sehari-hari, maka akhlak mahmudah itu akan tercapai, tentunya sangat diperlukan pula keterlibatan pemimpin dan penguasa bangsa ini untuk membuka peluang secara terus menerus menggalakkan gerakan agama ini, jika perlu menjadi bagian dari program pembangunan.

${ }^{9}$ Perjanjian manusia dengan Allah terjadi pada waktu Allah akan menciptakan manusia dan di sana terjadi dialog antara manusia dengan Tuhan, Ketika Alalh mengambil kesaksian manusia seraya berfirman,. "Bukankah Aku ini Tuhanmu?" dan manusia menjawab "Betul (Engkau Tuhan kami), kami menjadi saksi" (QS Al A'raf $7: 172$ )

10 Akhlak mahmudah disebut juga dengan Akhlak Karimah, yaitu akhlak yang terpuji atau akhlak yang mulia dan sangat besar artinya bagi kehidupan manusia, hingga wajib untuk dimiliki dan dijadikan hiasan hidup. karena hanya dengan akhlak yang terpuji inilah manusia akan dapat mempertahankan martabatnya selaku makhluk yang bagus. (Lihat Mustafa kamal dan Chusnan Jusuf , "Akhlak Sunnah II", 1978. hal. 16.

"Akhlak madzmumah atau disebut juga akhlak radzilah, yaitu akhlak yang tercela, yang rendah dan wajib dijauhi dengan sungguhsungguh. Akhlak ini bersesuaian dengan ajakan hawa nafsu manusia, hingga kalau tidak kuat mengendalikannya, maka seseorang akan mudah diseretnya ke lembah kehinaan. Dan akhlak inilah yang mengakibatkan manusia akan terpandang rendah dan terpandang hina dina tiada berharga di dalam pandangan Tuhan. (Ibid hal. 17). 


\section{Kesimpulan}

Rekonstruksi lembaga pengadilan adalah satu langkah yang dipilih untuk mengembalikan posisi pengadilan sebagai lembaga yang terhormat sejajar dengan lembaga-lembaga negara lainnya dan menempatkannya sebagai lembaga pelaksana kekuasan kehakiman yang menjangkau pada semua lapisan masyarakat. Rekonstruksi lembaga pengadilan tidak hanya terbatas pada bagian-bagian tertentu dari pengadilan melainkan menjangkau kepada keseluruhan komponen-komponen yang berhubungan dan berpengaruh terhadap kinerja lembaga pengadilan, yakni komponen struktural, peraturan hukum dan komponen manusianya.

Atas dasar komponen-komponen yang berpengaruh itu, maka rekonstruksi lembaga pengadilan, dapat dilakukan antara lain melalui upaya restrukturisasi pengadilan. Restrukturisasi pengadilan lebih di arahkan kepada persoalan-persoalan struktural berupa kedudukan organisasi, rekruitmen, jaminan profesi, kesejahteraan para hakim dan kewenangan khususnya mengenai hak uji materiil.

Upaya lainnya dapat dilakukan dengan melakukan reformasi terhadap perundangundangan. Reformasi ini dilakukan terhadap materi undang-undang yang tidak mendukung mekanisme kerja sebagai lembaga penegakan hukum. Untuk mendukung ke arah itu, maka reformasi ini dilakukan tidak saja pada dataran undangundang organik melainkan juga menjangkau pada dataran konstitusi (UUD)

Upaya restrukturisasi dan reformasi terhadap perundang-undangan tidak akan banyak artinya jika tidak diikuti dengan revitalisasi pengadilan sebab, berbagai perilaku pengadilan yang tidak menyenangkan

mengakibatkan melemahnya kepercayaan terhadap pengadilan itu sendiri. Oleh karena itu untuk mendukung kedua strategi tersebut, maka upaya revitalisasi pengadilan harus pula dilakukan dengan sasaran tumbuhnya kembali kesadaran akan peran dan tanggung jawab serta terjadinya perbaikan moralitas khususnya para hakim.

\section{Daftar Pustaka}

Barda Nawawi Arief, 1998, Beberapa Aspek Kebijakan Penegakan dan Pengembangan Hukum Pidana, Bandung : Penerbit Aditya Bakri. ."Sistem Peradilan

Pidana Terpadu Dalam Kaitannya Dengan Pembaharuan Kejaksaan, makalah disajikan pada forum "Dengar Pendapat Publik Pembaruan Kejaksaan, Jakarta, 24-25 Juni 2003.

Dahlan Thaib, "Struktur dan Organisasi Mahkamah Agung" makalah dalam Workshop "Perbaikan kedudukan, kekuasaan, Organisasi, Adiminstrasi dan Managemen Mahkamah Agung dan lain-lain badan Peradilan di bawahnya, diselenggarakan oleh IKAHI Yogyakarta tanggal 27-28 Agustus 2001.

Departement of International Economic and Social Affairs, Sevent United Nations Congress On The Prevention of Crime And The Treatment Of Offenders , 1986, Milan, 26 August-6 September 1985, New York: United Nations Publications.

Kuntoro Basuki dan Retnosupartinah, Kumpulan Undang-Undang Dan Peraturan-Peraturan Pemerintah 
Topik: Rekonstruksi Indonesia

Yang Berhubungan Dengan Masalah Peradilan 1980, Yogyakarta: Seksi Peradilan Fakultas Hukum UGM.

Lawrence M. Friedman, 1975, The Legal System, A Social Science Perspective, New York: Russell Sage Foundation.

Law And Society An Introduction 1977, United States of America Prentice-Hall, inc,. N.J. Ringlewood Cliffs.

Mustafa Kamal dan Chusnan Jusuf , 1978, "Akhlak Sunnah II".

Rusli Muhammad, "Urgensi Dan Upaya Revitalisasi Lembaga Peradilan", Jurnal Hukum No. 2 Vol 1 Tahun 1997.

"Reformasi Kekuasaan Kehakiman (Studi Sinkronisasi UUD 1945 dan UU. No. 14 Tabun 1970)", Jurnal Hukum \& Keadilan Vol. 1 number 1 tahun 1998.
Satjipto Rahardjo, 1983, Hukum dan Perubahan Sosial, Bandung: Penerbit Alumni

- - C-C- Pemberdayaan Mahkamah Agung ", dalam Gema Kliping Servis, Mei II 1997,

Shimon Shetreet dan Jules Deschenes, ed. 1985, "Judicial Independence The Conttemporary Debate," Netherlands: Martinus Nijhoff Publishers.

Soejono KoesoemoS, "Beberapa Pemikiran tentang Filsafat Hukum", Semarang: UNDIP, (tanpa tahun).

Sudikno Mertokusumo, "Revitalisasi dan Fungsionalisasi Lembaga Peradilan ", Makalah pada Diskusi "Usulan Rancangan GBHN '98, Yogyakarta: Fakultas Hukum UII, 15 Juli 1987.

Yusril Ihza Mahendra, 1996 "Adakah Kemerdekaan Kekuasaan Kehakiman", Makalah dalam seminar tentang Kekuasaan Kehakiman dan Sistem Peradilan di Indonesia, Semarang: Fak. Huk. UNDIP. 